http://jmscr.igmpublication.org/home/ ISSN (e)-2347-176x ISSN (p) 2455-0450 crossref DOI: https://dx.doi.org/10.18535/jmscr/v7i8.55

Journal Of Medical Science And Clinical Research

\title{
A Prospective Study of Changing Trend in the Clinical and Ultrasonographic Case Profile of Amoebic Liver Abscess - HIV Correlation and the Surgical Implications - In a Tertiary Care Hospital in North Andhra Pradesh
}

\author{
Dr Y.Padmanabham M.D (Micro) ${ }^{1}$, Prof. S. Srinivas M.D (GM) ${ }^{2}$, Dr P. K. Ranga Rao ${ }^{3}$ \\ ${ }^{1}$ Associate Professor, Dept of Microbiology, Gitam Institute of Medical Sciences and Research, Gitam \\ Deemed to be University, Visakhapatnam, Andhra Pradesh \\ ${ }^{2}$ Prof. Dept. of General Medicine and Gastroenterology, King George Hospital - Andhra Medical College, \\ Visakhapatnam \\ ${ }^{3}$ Clinical Cardiologist - Faculty, Dept of General Medicine, Gitam Institute of Medical Sciences and Research \\ *Corresponding Author \\ Dr K.Kodanda Rao M.S (G.S)
}

Faculty, Dept of General Surgery, Gitam Institute of Medical Sciences and Research, Gitam Deemed to be University, Visakhapatnam, Andhra Pradesh, India

\begin{abstract}
Introduction: In India due to poor sanitary condition and a lower socioeconomic status amoebiasis is endemic and amoebic liver abscess accounts for 3-9\% of all cases of amoebiasis. Amoebic liver abscess $(A L A)$ is the commonest extra intestinal manifestation of amoebiasis.

Aim: The aim of this work is to study the various presentations of amoebic liver abscess and HIV correlation to find any change in the clinical and radiological profile of ALA in recent years and to compare with other studies.

Materials and Methods: This study is conducted prospectively over a period of 2 years from December 2015 to November 2017 in the department of General Medicine, Andhra Medical College and King George Hospital, Visakhapatnam, Andhra Pradesh.

Study Design: Observational study.

Sample Size: Eighty patients were the confirmed diagnosis of ALA are included in this study.

Study Subjects: All patients who fulfill the diagnostic criteria for amoebic liver abscess are included in the study.

Results: In the present study, the incidence of amoebic liver abscess in the year 2016 is estimated to be 0.58/1000/year of 61,732 patients admitted in King George Hospital, Visakhapatnam whereas the incidence of HIV positive with amoebic liver abscess in the year 2016 is only 0.08/1000/year. Among HIV patients ALA is more intense in presentation and treatment if challenging.

Discussion: The present study has shown that the patterns of ALA largely parallels what has been established previously in terms of age, sex, onset, risk factors, clinical manifestations, number, size and location of abscess, treatment modalities and prognosis with few modifications.

Conclusions: It is concluded that amoebic liver abscess is a treatable condition having a good prognosis if it is recognized early and treated appropriately particularly among HIV patients.

Keywords: ALA, HIV, Clinical, Radiological, study.
\end{abstract}




\section{Materials and Methods}

This study is conducted prospectively over a period of 2 years from December 2015 to November 2017 in the department of General Medicine, Andhra Medical College and King George Hospital, Visakhapatnam, Andhra Pradesh.

Method of collection of data: Informed written consent is obtained from all the patients included in the study.

A proforma is designed and used for data collection. A detailed clinical history of the patient is taken regarding the present and past illnesses. All the patients are subjected to through clinical evaluation and laboratory investigations like urine examination, examination of stool for ova and cysts, examination of blood for hemoglobin, total leucocyte count (TLC), differential count, erythrocyte sedimentation rate (ESR) and liver function tests like serum bilirubin, serum alkaline phosphatase, SGPT, SGOT and serum albumin and hepatitis profile. X-ray chest, abdominal ultrasonography and aspiration of the abscess if $>6 \mathrm{~cm}$ size are also done.

All the patients with amoebic liver abscess included in the present study are screened for HIV infection in I.C.T.C. Centre in the Department of Microbiology ELISA. CD4 count is done if HIV infection is diagnosed.

Statistical Analysis: All recorded data are collected and analyzed using descriptive statistics. All the statistical analyses in this study are made using the Statistical Package for social Sciences (SPSS) software. Statistical significance level is accepted at $\mathrm{P}$-value equaled to 0.05 . Continuous variables are reported as mean + standard deviation (SD).

Data obtained from 80 cases of amoebic liver abscess admitted to Medical Wards of King George Hospital, Visakhapatnam. Andhra Pradesh during the period from December 2015 to November 2017 are taken. Among the 80 cases of ALA, $8(10 \%)$ patients had positive HIV test result and remaining 72 (90\%) patients are HIV - negative. This data forms the basis for the present study.

Ethical Clearance: Institutional ethical Committee has approved the conduct of the study. Incidence $=$ Total Number of cases / Population at risk $\mathrm{X} 1000=36 / 61,732 \mathrm{X} 1000=0.58 / 1000$ per year

\section{Exclusion Criteria}

- Patients below the age of 14 years are excluded from this study.

- In addition, patients whose specimen, such as blood or aspirate concomitantly isolated fungus or bacteria are excluded from this study to avoid the enrolment of patients with mixed infection.

HIV Seropositive Cases:

\begin{tabular}{|c|c|c|}
\hline \multicolumn{2}{|c|}{ Table 3: HIV Status of ALA cases } \\
\hline S.No & HIV Status & Number of Cases $(n=80)$ \\
\hline 1 & HIV-. Negative ALA cases & (72) $90 \%$ \\
\hline 2 & HIV-. Positive ALA cases & (8) $10 \%$ \\
\hline
\end{tabular}

\begin{tabular}{|c|c|c|c|c|c|c|c|}
\hline \multirow{2}{*}{ S.No } & \multirow{2}{*}{ Onset } & \multicolumn{2}{|c|}{$\begin{array}{l}\text { Total No. of } \\
\text { cases }\end{array}$} & \multicolumn{2}{|c|}{$\begin{array}{l}\text { HIV -ve } \\
(n=72)\end{array}$} & \multicolumn{2}{|c|}{$\begin{array}{c}\text { HIV + ve } \\
(n=8)\end{array}$} \\
\hline & & $\begin{array}{c}\text { No. } \\
(n=80)\end{array}$ & $\%$ & No. & $\%$ & No. & $\%$ \\
\hline 1 & Acute onset & 65 & 81.25 & 62 & 86.1 & 3 & 37.5 \\
\hline 2 & Subacute onset & 10 & 12.5 & 6 & 8.3 & 4 & 50 \\
\hline 3 & Chronic onset & 5 & 6.25 & 4 & 5.6 & 1 & 12.5 \\
\hline
\end{tabular}

Risk Factors:
\begin{tabular}{|c|l|c|c|}
\hline S.No & \multicolumn{1}{|c|}{ Risk factor } & Risk Factors of ALA \\
\hline 1 & Alcoholism & $\begin{array}{c}\text { No. of cases } \\
(\mathbf{n}=80)\end{array}$ & $\%$ \\
\hline 2 & History of Dysentery & 75 & 93.75 \\
\hline 3 & Diabetes Mellitus & 10 & 12.5 \\
\hline 4 & HIV & 8 & 10 \\
\hline 5 & HBV Hepatitis & 8 & 10 \\
\hline 6 & HCV Hepatitis & 2 & 2.5 \\
\hline 7 & IV Drug abuse & 0 & 0 \\
\hline
\end{tabular}


Clinical Symptoms:

Table 8: Clinical Symptoms of ALA

\begin{tabular}{|c|l|c|c|c|c|c|}
\hline $\begin{array}{c}\text { S. } \\
\text { No }\end{array}$ & \multicolumn{1}{|c|}{ Symptom } & $\begin{array}{c}\text { Total cases } \\
(\mathbf{n = 8 0})\end{array}$ & $\begin{array}{c}\text { HIV-ve }(\mathbf{n} \\
\mathbf{n} 72)\end{array}$ & $\begin{array}{c}\text { HIV+ve } \\
(\mathbf{n = 0 8})\end{array}$ & $\begin{array}{c}\text { Chis } \\
\text { quar } \\
\text { e }\end{array}$ & $\begin{array}{c}\text { P } \\
\text { value }\end{array}$ \\
\hline 1 & Fever & $85 \%(68)$ & $87.5 \%(63)$ & $62.5 \%(5)$ & 1.84 & 0.17 \\
\hline 2 & Abdominal pain & $86.5 \%(70)$ & $88.9 \%(64)$ & $75 \%(6)$ & 0.32 & 0.57 \\
\hline 3 & Pain right lower chest & $46.25 \%(37)$ & $47.2 \%(34)$ & $37.5 \%(3)$ & 0.02 & 0.88 \\
\hline 4 & $\begin{array}{l}\text { Ref. pain to right } \\
\text { shoulder }\end{array}$ & $15 \%(12)$ & $15.3 \%(11)$ & $12.5 \%(1)$ & 0.1 & 0.75 \\
\hline 5 & Jaundice & $16.25 \%(13)$ & $15.3 \%(11)$ & $25 \%(2)$ & 0.04 & 0.84 \\
\hline 6 & Nausea, Vomiting & $37.5 \%(30)$ & $37.5 \%(27)$ & $37.5 \%(3)$ & 0.15 & 0.69 \\
\hline 7 & $\begin{array}{l}\text { Cough \& } \\
\text { Expectoration }\end{array}$ & $10 \%(08)$ & $9.7 \%(7)$ & $12.5 \%(1)$ & 0.14 & 0.70 \\
\hline 8 & Breathlessness & $12.5 \%(10)$ & $12.5 \%(9)$ & $12.5 \%(1)$ & 0.32 & 0.57 \\
\hline 9 & Diarrhoea/Dysentery & $12.5 \%(10)$ & $9.7 \%(7)$ & $37.5 \%(3)$ & 2.86 & 0.09 \\
\hline
\end{tabular}

Clinical Signs:

Table 9: Clinical Signs of ALA

\begin{tabular}{|c|c|c|c|c|c|c|}
\hline $\begin{array}{c}\text { S.N } \\
0\end{array}$ & Clinical Sign & $\begin{array}{l}\text { No. of } \\
\text { cases } \\
(n=80)\end{array}$ & $\begin{array}{c}\text { HIV- } \\
\text { negative } \\
(\mathrm{n}=72)\end{array}$ & $\begin{array}{c}\text { HIV- } \\
\text { Infected } \\
(\mathrm{n}=08)\end{array}$ & $\begin{array}{l}\text { Chi } \\
\text { squa } \\
\text { re }\end{array}$ & $\stackrel{P}{P}$ value \\
\hline 1 & Hepatomegaly & $80 \%(64)$ & $80.6 \%(58)$ & $75 \%(6)$ & 0.01 & 0.92 \\
\hline 2 & $\begin{array}{l}\text { Abdominal } \\
\text { mass }\end{array}$ & $40 \%(32)$ & $40.3 \%(29)$ & $37.5 \%(3)$ & 0.05 & 0.82 \\
\hline 3 & $\begin{array}{l}\text { Abdominal } \\
\text { tenderness }\end{array}$ & $86.5 \%(70)$ & $88.9 \%(64)$ & $75 \%(6)$ & 0.32 & 0.57 \\
\hline 4 & $\begin{array}{l}\text { Intercostal } \\
\text { tenderness }\end{array}$ & $75 \%(60)$ & $76.4 \%(55)$ & $62.5 \%(5)$ & 0.19 & 0.66 \\
\hline 5 & Icterus & $16.25 \%(13)$ & $15.3 \%(11)$ & $25 \%(2)$ & 0.04 & 0.84 \\
\hline 6 & $\begin{array}{l}\text { Respiratory } S y s+ \\
\text { signs }\end{array}$ & $m 18.5 \%(15)$ & $18 \%(13)$ & $25 \%(2)$ & 0 & 1 \\
\hline
\end{tabular}

Ultrasonographic Features:

Table 11: Ultrasonographic Features in ALA

\begin{tabular}{|c|l|l|l|l|l|l|l|}
\hline $\begin{array}{c}\text { S. } \\
\text { No }\end{array}$ & \multicolumn{1}{|c|}{ Feature } & $\begin{array}{c}\text { No. of } \\
\text { cases } \\
(\mathbf{n = 8 0 )}\end{array}$ & $\begin{array}{c}\text { HIV- } \\
\text { negative } \\
(\mathbf{n = 7 2 )}\end{array}$ & $\begin{array}{c}\text { HIV- } \\
\text { Infected } \\
(\mathbf{n = 0 8 )}\end{array}$ & $\begin{array}{c}\text { Chi } \\
\text { squa } \\
\text { re }\end{array}$ & $\begin{array}{c}\text { p } \\
\text { value }\end{array}$ \\
\hline Location of ALA & \multicolumn{5}{|l|}{} \\
\hline 1 & Right Lobe abscess & $72.5 \%(58)$ & $75 \%(54)$ & $50 \%(4)$ & 1.18 & 0.27 \\
\hline 2 & Left Lobe abscess & $12.5 \%(10)$ & $12.5 \%(9)$ & $12.5 \%(1)$ & 0.32 & 0.57 \\
\hline 3 & Both lobes & $15 \%(12)$ & $12.5 \%(9)$ & $37.5 \%(3)$ & 1.84 & 0.17 \\
\hline Number of ALA & & & & & \\
\hline 1 & Single abscess & $77.5 \%(62)$ & $79.2 \%(57)$ & $62.5 \%(5)$ & 0.39 & 0.53 \\
\hline 2 & Multiple abscesses & $22.5 \%(18)$ & $20.8 \%(15)$ & $37.5 \%(3)$ & 0.39 & 0.53 \\
\hline
\end{tabular}

Laboratory parameters:

Table 12: Laboratory parameters in ALA

\begin{tabular}{|c|l|c|c|c|c|c|}
\hline $\begin{array}{c}\text { S. } \\
\text { No }\end{array}$ & Lab parameter & $\begin{array}{c}\text { No. of } \\
\text { cases } \\
(n=80)\end{array}$ & $\begin{array}{c}\text { HIV- } \\
\text { negative } \\
(n=72)\end{array}$ & $\begin{array}{c}\text { HIV- } \\
\text { Infected } \\
(n=08)\end{array}$ & $\begin{array}{c}\text { Chis } \\
\text { quar } \\
\text { e }\end{array}$ & P value \\
\hline 1 & Leucocytosis & $90 \%(72)$ & $94.4 \%(68)$ & $50 \%(4)$ & 11.25 & $0.0008^{*}$ \\
\hline 2 & Hb<10 g\% & $52.5 \%(42)$ & $52.8 \%(38)$ & $50 \%(4)$ & 0.05 & 0.82 \\
\hline 3 & $\begin{array}{l}\text { Elevated } \\
\text { S.bilirubin }\end{array}$ & $17.5 \%(14)$ & $16.7 \%(12)$ & $25 \%(2)$ & 0.01 & 0.92 \\
\hline 4 & Elevated SGPT & $26.25 \%(21)$ & $26.4 \%(19)$ & $25 \%(2)$ & 0.11 & 0.74 \\
\hline 5 & Elevated SGOT & $25 \%(20)$ & $25 \%(18)$ & $25 \%(2)$ & 0.19 & 0.66 \\
\hline 6 & Elevated ALP & $28.75 \%(23)$ & $29.2 \%(21)$ & $25 \%(2)$ & 0.03 & 0.86 \\
\hline 7 & $\begin{array}{l}\text { Decreased } \\
\text { Serum albumin }\end{array}$ & $12.5 \%(10)$ & $12.5 \%(9)$ & $12.5 \%(1)$ & 0.32 & 0.57 \\
\hline
\end{tabular}

Treatment:

Table 14: Treatment Modality in ALA

\begin{tabular}{|c|l|c|c|c|c|c|}
\hline $\begin{array}{c}\text { S. } \\
\text { No }\end{array}$ & Treatment option & $\begin{array}{c}\text { No. of } \\
\text { cases } \\
(\mathrm{n}=80)\end{array}$ & $\begin{array}{c}\text { HIV. } \\
\text { negative } \\
(\mathrm{n}=72)\end{array}$ & $\begin{array}{c}\text { HIV. } \\
\text { Infected } \\
(\mathrm{n}=08)\end{array}$ & $\begin{array}{c}\text { Chisqu } \\
\text { are }\end{array}$ & $\begin{array}{c}\mathrm{P} \\
\text { value }\end{array}$ \\
\hline 1 & Drug therapy only & $30 \%(24)$ & $29.2 \%(21)$ & $37.5 \%(3)$ & 0.01 & 0.92 \\
\hline 2 & Drug + Aspiration & $70 \%(56)$ & $70.8 \%(51)$ & $62.5 \%(5)$ & 0.01 & 0.92 \\
\hline 3 & Surgical & 0 & 0 & 0 & - & \\
\hline
\end{tabular}

Prognosis:

Table 15: Prognosis of ALA

\begin{tabular}{|l|l|l|c|c|c|c|}
\hline $\begin{array}{c}\text { S. } \\
\text { No }\end{array}$ & Parameter & $\begin{array}{c}\text { No. of cases } \\
(n=80)\end{array}$ & $\begin{array}{c}\text { HIV- } \\
\text { negative } \\
(n=72)\end{array}$ & $\begin{array}{c}\text { HIV- } \\
\text { Infected } \\
(n=08)\end{array}$ & $\begin{array}{c}\text { Chi } \\
\text { square }\end{array}$ & $\begin{array}{c}P \\
\text { value }\end{array}$ \\
\hline & Hospital stay & & & & & \\
\hline 1 & $<2$ weeks & $60 \%(48)$ & $62.5 \%(45)$ & $37.5 \%(3)$ & 0.98 & 0.32 \\
\hline & & & & & \\
\hline
\end{tabular}

2 Mortality 
Table showing comparison of Common Clinical Manifestations of ALA

\begin{tabular}{|c|c|c|c|c|}
\hline Study & Fever & $\begin{array}{l}\text { Abd. } \\
\text { Pain }\end{array}$ & Hepatomegaly & Jaundice \\
\hline Seeto RK et al. (1999) & $80 \%$ & $84 \%$ & $25 \%$ & $4 \%$ \\
\hline Wiwanitkit.V. et al. (2002) & $74 \%$ & $\begin{array}{c}85 \% \\
.\end{array}$ & $60 \%$ & $40 \%$ \\
\hline Amarapürkaret al. (2003) & $85 \%$ & $72 \%$ & $82 \%$ & $18 \%$ \\
\hline $\begin{array}{l}\text { Kuan-Sheng Wu et al. } \\
\text { (2008) }\end{array}$ & $100 \%$ & $75 \%$ & - & $32 \%$ \\
\hline Chen et al. (2009) & $90 \%$ & $81 \%$ & - & $11 \%$ \\
\hline $\begin{array}{l}\text { Mukhopadhyay et al. } \\
\text { (2010) }\end{array}$ & $80 \%$ & $100 \%$ & $82 \%$ & $15 \%$ \\
\hline Sharma et al. (2010) & $94 \%$ & $91 \%$ & $16 \%$ & $13 \%$ \\
\hline SoumikGhosh et al. (2014) & $94 \%$ & $99 \%$ & $89 \%$ & $26 \%$ \\
\hline Hoque Ml et al. (2014) & $93 \%$ & $93 \%$ & $67 \%$ & - \\
\hline $\begin{array}{l}\text { Raja Kalayarasan et al. } \\
\text { (2017) }\end{array}$ & $80 \%$ & $87 \%$ & & $43 \%$ \\
\hline Present Study & $85 \%$ & $86.5 \%$ & $80 \%$ & $16.25 \%$ \\
\hline
\end{tabular}

Table showing comparison of Ultrasonographic Features in ALA

\begin{tabular}{|c|c|c|c|c|c|}
\hline \multirow{2}{*}{ Study } & \multicolumn{3}{|c|}{ Location of abscess } & \multicolumn{2}{|c|}{ Abscess } \\
\hline & $\begin{array}{l}\text { Right } \\
\text { Lobe }\end{array}$ & $\begin{array}{l}\text { Left } \\
\text { Lobe }\end{array}$ & $\begin{array}{l}\text { Both } \\
\text { lobes }\end{array}$ & Single & Multiple \\
\hline Seeto RK et al. (1999) & $79 \%$ & $9 \%$ & $12 \%$ & $77 \%$ & $23 \%$ \\
\hline Wiwanitkit. V.et al. (2002) & $74 \%$ & $.11 \%$ & $15 \%$ & $77 \%$ & $23 \%$ \\
\hline Amarapurkar et al. (2003) & $90 \%$ & $10 \%$ & $\therefore$ & - & - \\
\hline Kuan-Sheng Wu et al. (2008) & $79 \%$ & - & - & $83 \%$ & $17 \%$ \\
\hline Chen et al. (2009) & $74 \%$ & $26 \%$ & 0 & $74 \%$ & $26 \%$ \\
\hline Mukhopadhyay et al. (2010) & $85 \%$ & $14 \%$ & $1 \%$ & $94 \%$ & $6 \%$ \\
\hline Sharma et al. (2010) & $65 \%$ & $13 \%$ & $22 \%$ & $78 \%$ & $22 \%$ \\
\hline Jha AK et al. (2012) & $80 \%$ & $18 \%$ & $2 \%$ & - & - \\
\hline Soumik Ghosh et al. (2014) & $71 \%$ & - & - & $65 \%$ & $35 \%$ \\
\hline Mallk M et al. (2014) & $92 \%$ & - & - & $81 \%$ & $19 \%$ \\
\hline Hoque Ml et al. (2014) & $77 \%$ & - & - & $80 \%$ & $20 \%$ \\
\hline Present Study & $72.5 \%$ & $12.5 \%$ & $15 \%$ & $77.5 \%$ & $22.5 \%$ \\
\hline
\end{tabular}

\section{Results and Discussion}

In the present study an effort is made to review the demographic data, to find out any variation in clinical profile, radiological profile, treatment outcome and to compare clinical presentations among the HIV positive and HIV negative patients.

Demographic Characteristics of ALS: In the present study, 80 cases of amoebic liver abscess admitted to Medical wards of King George Hospital, Visakhapatnam, Andhra Pradesh during the period from December 2015 to November 2017 are studied. Among the 80 ALA cases, 8 are found to be HIV positive. In the present study, the incidence of amoebic liver abscess is $0.58 / 1000 /$ year of 61,732 patients and the incidence of HIV positive amoebic liver abscess is $0.08 / 1000 /$ year of 61,732 patients admitted to medical wards of King George Hospital, Visakhapatnam from January 2016 to December 2016. Seeto et al. ${ }^{6}$ in his series noted the incidence of ALA was 8.5 patients/ 100,000 hospital admissions. A significant rise in the prevalence of HIV positive amoebic liver abscess was noted in the studies done by Meng-Shuian Hsu et al. on Taiwanese subjects. $80 \%$ of amoebic liver abscess occurring in the age group of 21 to 50 years. The mean age of patients with amoebic liver abscess in the present study is $41+102$ years, which is in accordance with other Indian studies like by Sharma et al., Soumik Ghosh et al. and Mukhopadhyay et al. who reported it to be $40.5,41$ and 43.64 years respectively. The resons for this male preponderance remains obscure, but high incidence of intestinal amoebiasis and aicohol abuse may be the factors behind the high incidence in males, while the hormonal milieu in female may provide protection against the disease. Reddy and Thangavelu proposed that the female menstrual cycle prevents hepatic congestion and thus makes the organ less susceptible to abscess formation. Ocshner and De Bakey attribute higher incidence in males to alcoholism, which predisposes to hepatitis and trauma. In the present study $75 \%$ of patients are alcoholics belonging to 
low socioeconomic group consuming non- refined alcohol like toddy and arrack. In the present study also most $(95 \%)$ of the oatients belong to lower socioeconomic class and is comparable to many of other studies from India like Sharma et al., Soumik Ghosh et al. and Mukhopadhyay et al. Majority $(81.25 \%)$ of patients in the present study are presented within 2 weeks of the start of symptoms. An acute presentation has become more common in recent years, probably because patients seek medical attention earlier and also non-invasive imaging studies facilitates disease detection early ${ }^{9}$.

Alcoholism Commonly believed to play some role in the aetiology of ALA and many patients give a past history of consuming it. Chronic alcoholism is the major risk factor identified for amoebic liver abscess in the present study and is found in 75 patients $(93.75 \%)$ and majority of patients consumed country liver in the form of toddy or arrack (cheep liquor). Mukhopadhyay et al. found that alcoholics had larger abscesses, greater frequency of complications and delayed resolution of patients had history of alcohol intake, and postulated that alcohol suppresses function of Kupffer cells in liver which has important role in clearing amoeba. ${ }^{6}$ Moreover, invasive amoebiasis appears to be dependent on the availability of free iron. A high content of iron in the diet, often obtained from the country liquor in habitual drinkers predisposes to invasive amoebiasis, as does a diet rich in carbohydrate. In the present study, $12.5 \%$ patients gave a past history of diarrhea/dysentery. Previous studies report it variably from $4 \%$ to $33 \%$. Soumik Ghosh et al. (2014) from Northern India had reported higher incidence of diarrhea in ALA in $23 \%$ of patients. The most common presenting symptoms in the study include abdominal pain (86.5\%) and fever $(85 \%)$. Previous reports have shown that abdominal pain and fever are two typical clinical symptoms that develop in over $85 \%$ patients with $\mathrm{ALA}^{5 .}$ In the present study $85 \%$ of patients presented with fever as compared to $57 \%$ in Vakil et al. series, $68.5 \%$ in Aptkar et al. series, $86 \%$ in
Nanda et al. series and 100\% in Kasliwal et al and Singh et al. series. Abdominal pain is observed in $86.5 \%$ of cases of ALA in the present study as compared to $75 \%$ in AIkat et al. series, $86 \%$ in Aptkar al. series and $100 \%$ in Kasliwal et al and Singh et al. series ${ }^{56}$.The common clinical signs of amoebic liver abscess in the present study are hepatomegaly (80\%), abdominal tenderness $(86.5 \%)$ and intercostals tenderness (75\%). Form India, Sharma.M.P.et al ${ }^{15}$ in a study of 70 cases of ALA found hepatomegaly in $84 \%$.

Jaundice: Jaudice is seen in $16.25 \%$ of patients in the present study. In earlier studies fron India, it was reported in $45-50 \%$ of patients.

Atypical Manifestations: In the present study $22.5 \%$ patients are presented with atypical manifestations, the most common among them are absence of hepatomegaly (20\%) followed by ascities with pedal edema (5\%), marked jaundice, acute abdomen and circulatory failure in $2.5 \%$ patients each. Mukhopadhyay. M. et al. and Joshi VR et al. observed that both jaundice and ascites tend to occur most commonly in the presence of multifocal abscesses.

\section{Ultrasonographic Features}

Abdominal ultrasound is still the diagnostic modality of choice for hepatic pathologies including liver abscess. In the present study, the right lobe is most frequently involved in $72.5 \%$ patients followed by isolated left lobe is most frequently involved in $72.5 \%$ patients followed by isolated left lobe abscess in $12.5 \%$ and combined involvement of bother lobes of liver in 12 patients $15 \%$ of patients. Similar high incidence of liver abscess in right lobe was reported by other contemporary studies like Sharma N et al. (65\%), Soumik Ghosh et al. ${ }^{44}(71 \%)$, Hoque MI et al. (77\%), Jha AK et al. (80\%), Mokhopadhyay M et al. (85\%) and Malik.P et al. (92\%).

The majority of amoebic liver abscesses (77.5\%) are solitary lesions in the present study and is comparable to other recent Indian studies like Sharma $\mathrm{N}$ et al. (78\%). Howue MI et al. (80\%), Malik.P et al. (81\%) and Mukhopadhyay $\mathrm{M}$ et al. (94\%). Multiple ALA are observed in $22.5 \%$ of 
patiens in the present study and is comparable to other studies by Sharma. N et al. (22\%), Hoque MI et al. ${ }^{62}$ (20\%) and Malik.P et al. (19\%). But Mukhopadhyay $\mathrm{M}$ et al. noticed multiple amoebic liver abscesses in $5.6 \%$ of patients only in their study.

\section{Laboratory Parameters}

The most common abnormal laboratory parameter among the 80 cases of amoebic liver abscess in the present study is leucocytosis $(90 \%)$ which is similar to many other studies like Mukhopadhyay $\mathrm{M}$ et al. Raised liver enzymes more than 3 times the normal occurred in $35 \%$ and $36 \%$ cases in the study by Sharma N. et al.

Elevated serum bilirubin is observed in $17.5 \%$ in the present study which is similar to that observed by Mukhopadhyay $M$ et al. (15\%) and Amarapurkar DN et al. (18\%).

\section{Treatment}

Similar to the present study, Mukhopadhyay M et al. $^{45}$ also observed that needle aspiration combined with chemotherapy represents a successful therapeutic approach in the treatment of ALA. But Amarapukar DN et al. in his study of ALA, noted majority of patients $(80 \%)$ improved with drug therapy alone and only $15 \%$ required percutaneous aspiration.

\section{Summary and Conclusion}

In the present study, 80 cases of amoebic liver abscess admitted to Medical wards of King George Hospital, Visakhapatnam. Andhra Pradesh during the period from December 2015 to November 2017 are studied. Among the 80 cases, $8(10 \%)$ are found to be HIV positive. The incidence of amoebic liver abscess in the present study in the year 2016 is estimated to be $0.58 / 1000 /$ year of hospital admissions whereas the incidence of HIV positive amoebic liver abscess is only $0.08 / 1000 /$ year. In the present study, highest number of amoebic liver abscess cases is recorded during the months of April to June which is attributable to the habit of toddy (fermented palm juice) drinking during the summer season.
Amoebic liver abscess cases are predominantly noted in males with maximum incidence in $3^{\text {rd }}, 4^{\text {th }}$ and $5^{\text {th }}$ decades of life. Majority if patients with ALA belong to lower socioeconomic group with regards to education, occupation, and per capita income. Acute onset is the most common presentation in ALA with HIV negative patients. Whereas subacute onset is common in ALA with HIV positive patients. Alcohol consumption in the from toddy or arrack (cheap liquor) is found to be major risk factor for amoebic liver abscess in the present study. The most common clinical features of ALA observed in the present study are fever, abdominal pain, hepatomegaly and intercostals tenderness. No obvious difference in clinical features between HIV-infected and HIV-negative patients could be indentified in the present study except for slightly more frequent occurrence of icterus and respirents of amoebic liver abscess. In the present study $22.5 \%$ patients are presented with atypical manifestations, the most common among them are absence of hepatomegaly, ascites with pedal edema, marked jaundice, acute abdomen and circulatory failure. Marked jaundice is more frequently observed in HIV positive patients than-HIV negative patients of amoebic liver abscess. Most of the amoebic liver abscess are found in the right lobe of liver and most often single. Multiple amoebic liver abscesses are observed in $22.5 \%$ of patients in the present study. The most common abnormal laboratory parameter among the ALA cases in the present study is leucocytosis $(90 \%)$. Leucocytosis is significantly more common in HIV-negative patients with ALA (94.4\%) than in HIV-infected patients (50\%). Majority of patients of ALA (70\%) needed both drug therapy and percutaneous needle aspiration for recovery. There is no statistically significant difference in treatment modalities between HIVinfected patients and HIV-negative patients with amoebic liver abscess. The during of hospital stay is relatively prolonged for than 2 weeks in HIVinfected patients with amoebic liver abscess $(62.5 \%)$ when compared to that of HIV-negative patients with amoebic liver abscess (37.5\%). 
It is concluded that amoebic liver abscess is a treatable condition having a good prognosis if it is recognized early and treated appropriately. The present study has shown that the patterns of ALA largely parallels what has been established previously in terms of age, sex, onset, risk factors, clinical manifestations, number, size and location of abscess, treatment modalities and prognosis with few modifications. In the present study, there is no significant difference in clinical manifestations, ultrasonographic features, laboratory data, treatment modalities and prognosis between HIV-positive patitents and HIV-negative patients with amoebic liver abscess except for a few.

\section{References}

1. Seeto RK, Rockey DC. Amebic liver abscess: epidemiology, clinical features, and outcome. West J Med 1999;170:104109.

2. Msltz G, Knauer CM. Amebic liver abscess: A 15-year experience. Am J Gastroenterol 1991;86:704-710.

3. Douglas G. Moore P Jr, Patterson M. A ten-year review of amebic abscess of the liver: 1959-1966. Am J Dig Dis 1968;13:709-717.

4. Katzenstein D, Rickerson V, Braude A. New concepts of amebic liver abscess derived from hepatic imaging, serodiagnosis, and hepatic enzymes in 67 consecutive cases in San Diego. Nedicine (Baltimore) 1982;61:237-246.

5. Akgun Y, Tacyildiz IH, Celik Y. Amebic liver abscess: Changing trends over 20 years. World J surg 1999;23:102-106.

6. Oh MD, Lee K, Kim E, et al. Amoebic liver abscess in HIV-infected patients. AIDS 2000;14:1872-1873.

7. Sharma MP, Sarin SK: Amoebic Liver Abscess in a North Indian Hospital-current trends. Brit J ClinPrac. 1987,41:789-93.

8. $\mathrm{Wu} \mathrm{KS}$, Tsai HC, Lee SS, et al. Comparison of clinical characteristics of amebic liver abscess in human immunodeficiency virus (HIV)-infected and non-HIV-infected patients. J Microbiollummunol Infect 2008;41:456.

9. Stanley SL Jr, Jackson TF, Foster L, Singh S. Longitudinal study of the antibody response to recombinant Entamoeba histolytica antigens in patients with amebic liver abscess. Am J Trop Med Hyg 1998;58;414.

10. Khanna S, Chaudhary D, Kumar A, Vij JC. Experience with aspiration in cases of amebic liver abscess in an endemic area. Eur J ClinMicrobiol Infect Dis 2005;24:428.

11. Sharma MP, Dasarathy S, Verma N, et al. Prognostic markers in amebic liver abscess: a prospective study. Am J Gastroenterol 1996; 91:2584.

12. Meng-Shuian Hsu, et al. Association between amebic liver abscess and Human Immunodeficiency Virus infection in Taiwanese subjects. BMC Infectious Diseases 2008.8:48.

13. Soumik Ghosh, Sourabh Sharma, A. K. Gadpayle, et al., "Clinical, Laboratory, and Management Prtofile in Patients of Liver Abscess from Northern India," Journal of Tropical Medicine , vol. 2014, Article ID 142382, 8 pages, 2014.

14. Mukhopdhyay M, Saha AK, Sarkar A, Mukherjee S. Amoebic liver abscess: presentation and complications. Indian Journal of Surgery 2012;72(1):37-41.

15. Mkkar RP, Sachdev GK, Malhotra V. Alcohol consumption, hepatic iron load and the risk of amoebic live abscess: a case control study. Internal Medicine. 2003;42(8):644-649.

16. Chuah S-K, Chang-Chien C-S, Sheen I-S, et al. The prognostic factors of severe amebic liver abscess: a retrospective study of 125 cases. The American Jounal of Tropical Medicine and Hygiene. 1992;46(4):398-402. 
17. Yoo HM, Kim WH, Shin SK, Chun WH, Kang JK, Park IS. The changing patterns of liver abscess during the past 20 years: a study of 482 cases. Yonsei Medical Journal. 1993;34(4):340-351.

18. Hoque MI, Uddin MS, Sarker AR, Uddin MK-Mymensingh. Common presentation of amebic liver abscess - a study in a tertiary care hospital in Bangladesh. Med J - October 1, 2014; (4); 724-9.

19. Jha AK, Das G, Maitra S, Sengupta TK, Sen S. Management of large amoebic liver abscess - a comparative study of needle aspiration and catheter drainage. $\mathrm{J}$ Indian Med Assoc - January 1, 2012; 110 (1); 135.

20. Malik. P, H N Lakshmi, M Rathi, D Saini, R Saini, R Arya. A Prospective Study Of Liver Abscesses: Clinical Profile And Management Of 100 Cases Admitted In A Single Surgical Unit Of the SMS Hospital In Jaipur, India. The Internet Journal of Infectious Diseases. 2014 Volume 13 Number 1.

21. Ramani A, Ramani R, Kumar MS, Lkshkar BN, Kundae GN (1993) Ultrasound-guided needle aspiration of amoebic liver abscess. Postgrad Med J 69(811):381-383.

22. Viroj Wiwanitkit. A note on clinical presentations of amebic liver abscess: an overview from 62 Thai patients. BMC Family Practice 2002,3

23. Hsu MS, Hsieh SM, Chen MY, Hung CC, Chang SC, Association between amebic liver abscess and human immunedeficiency virus infection in Taiwaness subjects. BMC Inf Dis. 2008;48-52

24. Chen KJ, Yang CH, Lin YC, Liu HY, Liao ST, Lee YJ. Characteristics of amebic liver abscess in patients with or without human immunodeficiency virus. J Microbiollmmunol Infect. 2009 Dec;42(6):500-4.

25. Jessurun J, Barron-Rodriguez LP, Fernandez-Tinoco G, Hernandez- Avila M
The prevalence of invasive amebiasis is not increased in patients with AIDS. AIDS 1992;6:307-9 doi: 10.1097/00002030199203000-00007.

26. Hung CC, Chen PJ, Hsieh SM, Wrong JM, Fang CT, Chang SC, et al. Invasive qamoebiases: an emerging parasitic disease in patients infect3ed with HIV in an area endemic for amoebic infection. AIDS 1999;13:2421-8doi: 10.1097/00002030-199912030-00014. 